\title{
Modal Sosial dan Keberlanjutan Usahatani Jagung di Kecamatan Tanjung Lago Kabupaten Banyuasin
}

\author{
Social Capital and Sustainability Level of Maize Farm \\ in Tanjung Lago Sub-District Banyuasin District
}

\author{
Azqia Wardani \\ M. Yazid* \\ Yunita \\ Fakultas Pertanian, Universitas Sriwijaya, Sumatera Selatan, Indonesia \\ ${ }^{*}$ Email: yazid_ppmal@yahoo.com
}

\begin{abstract}
The existence of social capital has an equally important with economic capital. Social capital is an important factor for farmers to innovate and support sustainability. Sustainable agriculture can be realized in a way that every farm must be oriented to the process of achieving profitable and efficient production by emphasizing on improving disease management and prevention. Banyuasin Regency is one of the largest regencies that produce corn in the province of South Sumatra. The sub-district that produces the most corn is Tanjung Lago District. Thus, it is necessary to measure social capital in supporting the sustainability of maize farming. This study aims to measure (1) the social capital of corn farmers in Tanjung Lago District; (2) the sustainability of maize farming in Tanjung Lago District. The research location was determined intentionally. Sampling using simple random sampling technique. The data used are primary data and secondary data which were analyzed by tabulation then analyzed mathematically and described descriptively. The results showed that (1) the social capital of farmers in the research location was in the medium category; (2) the opportunity for the sustainability of maize farming in Tanjung Lago District, Banyuasin Regency is worth $54.47 \%$, meaning that it is quite sustainable.
\end{abstract}

Keywords: maize farm, social capital, sustainability

\begin{abstract}
ABSTRAK
Keberadaan modal sosial memiliki peran yang sama penting dengan modal ekonomi. Modal sosial merupakan faktor penting bagi petani untuk melakukan inovasi dan mendukung keberlanjutan. Pertanian berkelanjutan dapat diwujudkan dengan cara setiap usahatani harus berorientasi pada proses pencapaian produksi yang menguntungkan dan efisien dengan menekankan pada perbaikan manajemen dan pencegahan penyakit. Kabupaten Banyuasin termasuk kabupaten/kota terbesar yang memproduksi tanaman jagung di provinsi Sumatera Selatan. Kecamatan yang paling banyak menghasilkan jagung adalah Kecamatan Tanjung Lago. Dengan demikian, perlu diukur mengenai modal sosial dalam mendukung keberlanjutan usahatani jagung. Penelitian ini bertujuan untuk mengukur (1) modal sosial petani jagung di Kecamatan Tanjung Lago; (2)
\end{abstract}


keberlanjutan usahatani jagung di Kecamatan Tanjung Lago. Lokasi penelitian ditentukan dengan sengaja (Purposive Method). Pengambilan sampel menggunakan teknik simple random sampling. Data yang digunakan adalah data primer dan data sekunder yang dianalisis secara tabulasi kemudian dianalisis secara matematis dan diuraikan secara deskriptif. Hasil penelitian menunjukkan bahwa (1) Modal sosial petani di lokasi penelitian berada pada kategori sedang; (2) peluang keberlanjutan usahatani jagung di Kecamatan Tanjung Lago Kabupaten Banyuasin bernilai 54,47 \% artinya cukup berkelanjutan.

Kata Kunci: usahatani jagung, modal sosial, keberlanjutan

\section{PENDAHULUAN}

Strategi pengembangan agribisnis berorientasi terhadap pendayagunaan berbagai kualitas sumber daya di setiap daerah, akomodatif terhadap kualitas sumberdaya manusia, tidak mengandalkan pinjaman luar negeri, serta dapat mengekspor hasil produksi. Maka strategi pembangunan agribisnis akan digerakkan oleh barang modal dan sumber daya manusia yang lebih terampil dengan memanfaatkan ilmu pengetahuan, dan teknologi sehingga mampu mengantarkan perekonomian Indonesia memiliki daya saing tinggi.

Program berorientasi pada pemberdayaan perlu dilaksanakan untuk memperlancar kegiatan petani didukung dengan adanya partisipasi dan dukungan dari warga setempat. Program yang disusun sesuai dengan kebutuhan masyarakat atau anggota kelompok tani. Masyarakat akan tergerak untuk berpartisipasi apabila partisipasi tersebut dilakukan melalui organisasi yang telah dikenal atau yang sudah ada di tengah masyarakat yang bersangkutan.

Terjamin dan terselenggaranya program pemberdayaan yang dilakukan harus mengadopsi keberadaan modal sosial yang berkembang di masyarakat. Modal sosial merupakan modal yang lebih menekankan pada modal yang dimiliki masyarakat sebagai hasil dari hubungan-hubungan sosial yang terjalin diantara semua anggota (Solikatun, 2018).

Keberadaan modal sosial memiliki peran yang sama pentingnya dengan keberadaan modal ekonomi dalam proses pemberdayaan. Pengimplementasian suatu kebijakan yang berkaitan dengan pemberdayaan masyarakat tentunya perlu memperhatikan keberadaan modal sosial. Modal sosial termasuk dalam dimensi sosial dari paradigma pembangunan berkelanjutan yang mengintegrasikan tiga dimensi, yaitu sosial, ekonomi, dan lingkungan.

Kebijakan pemerintah Indonesia yang berhubungan dengan pertanian berkelanjuan disusun sesuai konsep dari Food Agricultural Organization (FAO) terkait pembangunan pertanian berkelanjutan. Melalui konferensi PBB telah ditekankan mengenai pentingnya pertanian berkelanjutan untuk memberikan kontribusi terhadap ketahanan pangan dan pengelolaan sumber daya alam. Pertanian berkelanjutan dapat diwujudkan dengan cara setiap usahatani harus berorientasi pada proses pencapaian produksi yang 
menguntungkan dan efisien dengan menekankan pada perbaikan manajemen dan pencegahan penyakit (Khaswarina, 2018).

Sistem pertanian berkelanjutan dalam jangka panjang artinya sistem ini dapat mempertahankan dan meningkatkan kualitas lingkungan, menyediakan insentif sosial dan ekonomi untuk semua pelaku dalam sistem produksi, serta memproduksi dalam jumlah yang cukup dan masing-masing penduduk memiliki akses terhadap produk yang dihasilkan. Kriteria pertanian berkelanjutan meliputi kelayakan ekonomi, ramah lingkungan, adil secara sosial, sesuai dengan budaya setempat, dan sistem pertanian berkelanjutan berbasis pengetahuan yang multidisiplin, serta mempertimbangkan interaksi dinamis antara aktivitas on-farm dan non on-farm. Teknologi tepat guna, kebijakan, dan pengelolaan sumberdaya sesuai dengan keunggulan komparatif dan kompetitif suatu wilayah sangat diperlukan untuk mewujudkan tujuan pembangunan pertanian berkelanjutan (Dewi, 2020).

Berdasarkan data Badan Pusat Statistik, Kabupaten Banyuasin termasuk kabupaten/kota terbesar yang memproduksi tanaman jagung di provinsi Sumatera Selatan. Adapun kecamatan yang paling banyak memproduksi tanaman jagung adalah Kecamatan Tanjung Lago, Kecamatan Muara Sugihan, dan Kecamatan Muara Telang. Di antara ketiga kecamatan tersebut, kecamatan dengan luas panen terbesar komoditi jagung ialah Kecamatan Tanjung Lago yang mencapai 9.271 ha dibandingkan dua kecamatan tersebut masing-masing sebesar 8.531 ha dan 1.012 ha (Dinas Pertanian Tanaman Pangan dan Hortikultura Kab. Banyuasin, 2019).

Menurut penelitian yang dilakukan oleh Mamahit, et al., 2016 modal sosial telah mampu meningkatkan eksistensi serta kekompakan pada suatu kelompok tani. Modal sosial satu kelompok tani dibandingkan dengan kelompok tani lain yang unsur - unsur modal sosial di dalamnya sudah berkurang bahkan tidak ada lagi sehingga membuat kelompok ini kurang aktif.

Menurut Rahayu, 2019 salah satu kondisi yang dialami oleh petani terutama untuk komoditas tanaman pangan adalah rendahnya produktivitas. Salah satu faktor yang dapat menaikkan produktivitas adalah nilai modal sosial yang dimiliki di suatu daerah yang dapat membantu petani pada produksi, distribusi, dan inovasi. Modal sosial yang ditandai dengan banyaknya jumlah kelompok tani di pedesaan dapat mempercepat tersalurnya aspirasi petani.

Penelitian ini sangat menarik untuk dikaji. Tujuan penelitian ini adalah untuk mengukur (1) modal sosial petani jagung di Kecamatan Tanjung Lago; (2) keberlanjutan Usahatani Jagung di Kecamatan Tanjung Lago.

\section{METODE PENELITIAN}

Penelitian ini dilakukan di Desa Mulia Sari dan Desa Banyu Urip Kecamatan Tanjung Lago Kabupaten Banyuasin. Pemilihan lokasi dilakukan secara purposive (sengaja) dengan pertimbangan bahwa kecamatan ini merupakan kecamatan yang paling banyak memproduksi jagung di Kabupaten Banyuasin. Metode yang digunakan dalam penelitian ini adalah metode survei. Metode penarikan contoh yang digunakan dalam penelitian 
adalah metode simple random sampling. Penentuan jumlah sampel menggunakan rumus Slovin karena populasi petani jagung sudah diketahui. Dengan demikian, sampel yang digunakan sebanyak 90 petani.

Data yang dikumpulkan pada penelitian ini terdiri dari dua jenis data yaitu data primer dan data sekunder. Data primer dilakukan melalui observasi dan wawancara langsung dengan petani di Kecamatan Tanjung Lago berdasarkan pertanyaan di kuisioner. Sedangkan data sekunder diperoleh melalui studi pustaka, yakni melakukan penelaahan terhadap publikasi data dari lapangan, Badan Pusat Statistik (BPS), hasil penelitian, dan buku-buku pustaka lainnya yang berhubungan dengan penelitian ini.

Untuk menjawab rumusan masalah pertama yaitu menganalisis keadaan modal sosial petani jagung di Kecamatan Tanjung Lago akan digunakan Skala Likert. Data diukur dengan tiga indikator, yaitu norma, kepercayaan, dan jaringan. Ketiga indikator tersebut masing-masing memiliki lima pertanyaan. Setiap pertanyaan diberi skor 5 untuk kriteria sangat tinggi, skor 4 untuk kriteria tinggi, skor 3 untuk kriteria sedang, skor 2 untuk kriteria rendah dan skor 1 untuk kriteria sangat rendah.

Analisis yang digunakan untuk menjawab rumusan masalah kedua yaitu menilai keberlanjutan usahatani jagung adalah metode RAP (Rapid Appraisal Technique) menggunakan Multidimensional Scalling (MDS). Keberlanjutan usahatani jagung dilihat dari tiga dimensi yaitu sosial, ekonomi, dan lingkungan. Skala pengkuran yang digunakan adalah skala ordinal, dimana skala ini tidak hanya mengkategorikan variabel ke dalam kelompok tetapi juga melakukan rangking terhadap kategori. Rangking yang digunakan menggunakan skor 1 sampai dengan 5.

Ordinasi Rapfish ditempatkan pada kurva dua dimensi. Dimensi horizontal (sumbu X) memiliki arti penting dalam ordinasi. Sumbu Y memberikan variasi dalam indikator dan tidak berhubungan sama sekali dengan derajat keberlanjutan. Sumbu Y dibuat secara arbitraty (arbitrer) dan dihasilkan dari separuh skor bad (down) dan skor good (up).

Dalam MDS, objek atau titik yang diamati dipetakan ke dalam ruang dua atau tiga dimensi, sehingga objek atau titik tersebut diupayakan ada sedekat mungkin terhadap titik asal. Teknik ordinasi di dalam MDS didasarkan pada Euclidian Distance yang dalam ruang yang berdimensi $\mathrm{n}$ ditulis sebagai berikut.

$\mathrm{d}_{\mathrm{ij}}=\sqrt{\left[(x i-x j)^{2}+(y i-y j)^{2}\right]}$

Keterangan :

$\mathrm{x}_{\mathrm{i}}$ dan $\mathrm{x}_{\mathrm{j}}=$ koordinat $\mathrm{x}$ untuk fasilitas 1 dan 2

$\mathrm{y}_{\mathrm{i}}$ dan $\mathrm{y}_{\mathrm{j}}=$ koordinat $\mathrm{y}$ untuk fasilitas 1 dan 2

$\mathrm{d}_{\mathrm{ij}}=$ jarak antara fasilitas $\mathrm{i}$ dan $\mathrm{j}$

Konfigurasi atau ordinasi dari suatu obyek atau titik di dalam MDS kemudian diaproksimasi dengan meregresikan jarak Euclidian $\left(\mathrm{d}_{\mathrm{ij}}\right)$ dari titik i ke titik j dengan titik asal $\left(\mathrm{d}_{\mathrm{ij}}\right)$ dengan persamaan di bawah ini:

$\mathrm{d}_{\mathrm{ij}}=\mathrm{a}+\mathrm{bd}_{\mathrm{ij}}+\mathrm{e}$

untuk meregresikan persamaan di atas dapat menggunakan metode algoritma ASCAL. Selanjutnya metode ASCAL mengoptimisasi jarak kuadrat (squared distance $=\mathrm{d}_{\mathrm{ij}}$ ) 
terhadap data kuadrat (titik asal $=\mathrm{O}_{\mathrm{ij}}$ ), yang dalam tiga dimensi ditulis dalam formula yang disebut $\mathrm{S}$-Stress sebagai berikut.

$\mathrm{S}=\sqrt{\frac{1}{m} \sum_{k=1}^{m} \frac{\sum i \sum j\left(\text { dijk }^{2}-o i j k^{2}\right)^{2}}{\sum i \sum j o i j k 4}}$

Jarak kuadrat merupakan jarak Euclidian yang dibobot atau ditulis:

Dijk $2=\sum_{a-1}^{y}$ wka $(\text { xia }-\mathrm{x} \mathrm{ja})^{2}$

Algoritma ASCAL kemudian melakukan proses iterasi untuk meminimalkan eror. Iterasi ini akan berhenti ketika goodness of fit yang diukur melalui $s$-stress nilai minimum, dimana nilai-nilai s-stress yang rendah menunjukkan good of fit sementara nilai s-stress yang tinggi sebaliknya. Di dalam Rapfish model yang baik ditunjukkan dengan nilai stress yang lebih kecil dari 0,25.

Dalam analisis Rapfish juga terdapat nilai RSQ (Squared Correlation) yang digunakan untuk mengetahui kedekatan antara data dengan perceptual map. Apabila nilai RSQ semakin mendekati 1 berarti data yang ada semakin terpetakan dengan sempurna.

Tabel 1. Kategori Status Keberlanjutan

\begin{tabular}{cc}
\hline Nilai indeks keberlanjutan & Kategori \\
\hline $0-25$ & Buruk (tidak berkelanjutan) \\
$26-50$ & Kurang (kurang berkelanjutan) \\
$51-74$ & Cukup (cukup berkelanjutan) \\
$75-100$ & Baik (berkelanjutan) \\
\hline
\end{tabular}

Leveraging pada prinsipnya mendeteksi atribut dominan. Perhitungan Leveraging memungkinkan kita untuk melihat perubahan ordinasi (posisi bad-good) ketika atribut tersebut satu persatu dikeluarkan. Dalam Rapfish, nilai leverage diukur skor pada setiap atribut dengan perhitungan Root Mean Square (RMS). Root mean square artinya dikuadratkan, lalu diambil rata-ratanya, kemudian diakarkuadratkan. Jadi, jika ada sekumpulan pengukuran $\{\mathrm{xi}\}$ (dengan indeks $1,2, \ldots, \mathrm{N}$ menunjukkan nilai pengukuran ke-i), untuk mendapatkan nilai rms-nya:

1. Kuadratkan setiap nilai pengukuran $\chi_{1}^{2}, \chi_{2}^{2}, \ldots, \chi_{N^{2}}$

2. Rata-ratakan, $\frac{1}{N} \sum_{i}^{N}\left(\chi_{\mathrm{i}}\right)^{2}=\mathrm{y}$

3. Akar kuadratkan, $\sqrt{y}=\chi_{\text {rms }}$

$$
\bar{\chi}=\sqrt{\frac{\sum_{i=1}^{N} \mathrm{xi}^{2}}{N}}
$$

Fitur ketiga dari Rapfish adalah Monte Carlo sebagai uji validitas dan ketepatan. Analisis ini untuk melihat tingkat kestabilan hasil analisis ordinasi. Jika hasil analisis Monte Carlo tidak merubah secara signifikan atau memiliki perbedaan nilai ordinasi yang kecil dapat disimpulkan bahwa hasil ordinasi MDS dapat mengatasi adanya kesalahan acak. Analisis Monte Carlo sebagai metode untuk menganalisis perambatan ketidakpastian yang tujuannya untuk menentukan bagaimana variasi acak atau error yang mempengaruhi sensitivitas, performa, atau reliabilitas (konsistensi) dari sistem yang dimodelkan (Mahida, 2019). 


\section{HASIL DAN PEMBAHASAN}

\section{Modal Sosial Petani Jagung di Kecamatan Tanjung Lago Kabupaten Banyuasin}

Modal sosial perlu diperhatikan dalam kegiatan usahatani. Hal ini didukung oleh penelitian Honorita, et al., 2019 yang menyatakan kontribusi modal sosial terhadap perilaku petani sebesar 86,1 persen. Modal sosial petani jagung diukur dengan tiga indikator yaitu norma yang berlaku di desa, kepercayaan antar petani, dan jaringan petani.

Tabel 2. Modal Sosial Petani Jagung di Kecamatan Tanjung Lago Kabupaten Banyuasin

\begin{tabular}{llcc}
\hline No & Komponen Pengukuran & Skor Rata-rata & Kriteria \\
\hline 1 & Norma yang ada di desa & 3,47 & Tinggi \\
2 & Kepercayaan antar petani & 3,07 & Sedang \\
3 & Jaringan petani & 3,17 & Sedang \\
& Jumlah & 9,71 & \\
\hline & Rata-rata & 3,24 & Sedang \\
\hline
\end{tabular}

Berdasarkan pengukuran indikator modal sosial petani di Kecamatan Tanjung Lago memperoleh skor 3,24 artinya modal sosial petani termasuk dalam kriteria sedang. Hal ini sejalan dengan penelitian yang dilakukan oleh Pratiwi, 2017 yang menyatakan bahwa peran modal sosial pada kelompok tani yang ditelitinya belum maksimal dalam membangun jejaring pemasaran atau masih tergolong sedang.

Pada komponen pengukuran norma yang ada di desa termasuk dalam kategori tinggi. Hal ini menunjukkan bahwa petani di desa sudah menaati peraturan yang berlaku. Dengan demikian, permasalahan yang ada di desa tidak terjadi karena seluruh petani mematuhi peraturan yang berlaku. Pada komponen pengukuran kepercayaan antar petani termasuk dalam kategori sedang. Modal sosial dapat terbentuk dengan baik apabila rasa percaya dimiliki oleh setiap petani.

Pada komponen pengukuran jaringan petani termasuk dalam kategori sedang. Hal ini sejalan dengan rasa percaya yang dimiliki oleh antar petani yang juga berada pada kategori sedang. Hal tersebut menunjukkan bahwa jaringan antar petani perlu ditingkatkan agar segala sesuatu kegiatan usahatani dapat berjalan dengan lancar.

\section{Modal Sosial yang Diukur dari Indikator Norma}

Norma berarti sejumlah peraturan yang terdapat di desa yang bertujuan untuk menciptakan kerukunan. Norma ini diukur dari lima pertanyaan yaitu mentaati semua aturan yang ada dalam desa, mengikuti program asuransi pertanian, membayar pajak bumi dan bangunan, melaksanakan program kerja dari kelompok tani, dan saling tolong menolong jika ada permasalahan terutama dalam berusahatani jagung. 
Tabel 3. Modal Sosial yang diukur berdasarkan Norma yang Berlaku

\begin{tabular}{|c|c|c|c|}
\hline No. & Indikator & $\begin{array}{l}\text { Skor rata- } \\
\text { rata }\end{array}$ & Kriteria \\
\hline 1 & Mentaati semua aturan yang ada dalam desa & 4,32 & Sangat Tinggi \\
\hline 2 & Mengikuti program asuransi pertanian & 1,49 & Sangat Rendah \\
\hline 3 & \multirow{2}{*}{$\begin{array}{l}\text { Membayar pajak bumi dan bangunan } \\
\text { Melaksanakan program kerja dari kelompok } \\
\text { tani }\end{array}$} & 4,11 & Tinggi \\
\hline 4 & & 3,63 & Tinggi \\
\hline \multirow[t]{3}{*}{5} & $\begin{array}{l}\text { Saling tolong menolong jika ada } \\
\text { permasalahan terutama dalam berusahatani } \\
\text { jagung }\end{array}$ & 3,78 & Tinggi \\
\hline & Jumlah & 17,33 & \\
\hline & Rata-rata & 3,47 & Tinggi \\
\hline
\end{tabular}

Pada indikator pengukuran pertama yaitu mentaati semua aturan yang ada dalam desa memiliki skor 4,32 dengan kriteria sangat tinggi. Hal ini menandakan semua petani sudah mematuhi aturan. Sedangkan mengikuti program asuransi pertanian memiliki skor ratarata 1,49 dengan kriteria sangat rendah. Hal ini berarti petani di desa tidak mengikuti program asuransi pertanian. Asuransi pertanian sudah disosialisasikan ke para petani. Akan tetapi, petani tidak berminat untuk mengikuti program asuransi pertanian karena mereka mengganggap hal itu kurang praktis. Adapun alasan lainnya adalah petani di lokasi penelitian tidak pernah mengalami gagal panen yang merugikan, sehingga asurasni pertanian tidak dibutuhkan oleh para petani tersebut.

Kemudian indikator pengukuran membayar pajak bumi dan bangunan bernilai 4,11 dengan kriteria tinggi. Hal ini tidak ada masalah dalam membayar pajak. Petani di desa sudah tepat waktu membayar pajak. Lalu, melaksanakan program kerja dari kelompok tani memiliki skor rata-rata 3,63 dengan kriteria tinggi. Petani tentunya telah mengikuti program kerja yang ada dengan baik. Program kerja yang ada di lokasi penelitian adalah membersihkan saluran air, penanaman serentak, membuat jalan ke sawah.

Indikator pengukuran yang kelima adalah saling tolong menolong jika ada permasalahan terutama dalam berusahatani jagung memiliki skor rata-rata 3,78 dengan kriteria tinggi. Saat petani diwawancarai, petani menjawab bersedia akan membantu sesama petani apabila memiliki permasalahan dalam melakukan usahatani.

\section{Modal Sosial yang Diukur dari Indikator Kepercayaan Petani}

Kepercayaan merupakan suatu asumsi, harapan, atau keyakinan yang dimiliki seorang petani dan ditujukan kepada petani lainnya bahwa petani tersebut berperilaku seperti yang diharapkan dan dibutuhkan agar dapat membentuk kerja sama yang baik. Apabila kepercayaan antar petani dimiliki dengan baik, maka tidak akan memunculkan konflik. Kepercayaan ini diukur dari lima pertanyaan yaitu hubungan kekerabatan yang erat antar petani, percaya terhadap pengurus kelompok tani, peminjaman alsintan antar petani berjalan dengan lancar, saling mendukung segala sesuatu kegiatan yang dilaksanakan antara ketua dan anggota kelompok tani, dan kesiapan dalam menggunakan teknologi informasi untuk pertemuan kelompok tani. 
Tabel 4. Modal Sosial yang diukur berdasarkan Kepercayaan Petani

\begin{tabular}{|c|c|c|c|}
\hline No. & Indikator & $\begin{array}{l}\text { Skor rata- } \\
\text { rata }\end{array}$ & Kriteria \\
\hline 1 & Hubungan kekerabatan yang erat antar petani & 3,33 & Sedang \\
\hline 2 & Percaya terhadap pengurus kelompok tani & 3,12 & Sedang \\
\hline 3 & $\begin{array}{l}\text { Peminjaman alsintan antar petani berjalan dengan } \\
\text { lancar }\end{array}$ & 2,96 & Sedang \\
\hline 4 & $\begin{array}{l}\text { Saling mendukung segala sesuatu kegiatan yang } \\
\text { dilaksanakan antara ketua dan anggota kelompok tani }\end{array}$ & 3,39 & Sedang \\
\hline 5 & $\begin{array}{l}\text { Kesiapan dalam menggunakan teknologi informasi } \\
\text { untuk kegiatan pertemuan kelompok tani }\end{array}$ & 2,57 & Rendah \\
\hline & Jumlah & 15,37 & \\
\hline & Rata-rata & 3,07 & Sedang \\
\hline
\end{tabular}

Menurut Harahap, 2018 menyatakan kepercayaan antar anggota kelompok tani menggambarkan bagaimana modal sosial yang terbentuk pada kehidupan masyarakat di lokasi penelitian. Kepercayaan merupakan salah satu elemen pokok yang akan menentukan apakah suatu masyarakat memiliki kekuatan modal sosial atau tidak. Unsur ini memiliki kekuatan penggerak energi kolektif yang sangat tinggi karena kepercayaan senantiasa dipandang penting.

Pada indikator pengukuran pertama yaitu hubungan kekerabatan yang erat antar petani memiliki skor rata-rata 3,33 dengan kriteria sedang. Petani belum menjadikan petani lain sebagai kerabat yang paling dekat. Petani biasanya menghubungi keluarga terlebih dahulu apabila terdapat suatu masalah.

Indikator pengukuran yang kedua yaitu percaya terhadap pengurus kelompok tani juga memiliki kriteria sedang dengan skor rata-rata 3,12. Beberapa petani berpendapat mengenai pupuk yang dikeluarkan kepada petani tidak tepat waktu. Padahal petani sebenarnya sudah menggunakan pupuk yang berlebihan. Adapun ketentuan pupuk dari gapoktan adalah mendapatkan pupuk SP36 sebanyak dua karung, urea empat karung, dan phonska empat karung untuk setiap satu musim tanam. Setiap kelompok tani mempunyai uang kas sebanyak 5.000 per karung. Uang tersebut digunakan untuk membantu kegiatan gotong royong yang ada di desa seperti membangun musholla dan membuat jalan ke arah sawah.

Indikator pengukuran ketiga adalah peminjaman alsintan antar petani berjalan dengan lancar memiliki kriteria sedang dengan skor rata-rata 2,96. Adapun alsintan yang dimaksud adalah combine harvester dan jonder. Petani tidak terlalu merasakan manfaat dari meminjam alat tersebut karena harus membayar sewa peminjaman alat dengan sistem borongan. Selain itu, beberapa petani juga tidak ingin menunggu lama karena meminjam alat membutuhkan waktu sedikit lama untuk bergantian dengan petani lainnya. Oleh karena itu, petani lebih baik membayar sewa.

Indikator yang keempat adalah saling mendukung segala sesuatu kegiatan yang dilaksanakan antara ketua dan anggota kelompok tani memiliki kriteria sedang dengan 
skor 3,39. Petani mengikuti peraturan yang sudah diterapkan oleh ketua dengan membayar kas dan penanaman jagung yang serentak.

Indikator yang kelima adalah kesiapan dalam menggunakan teknologi informasi untuk kegiatan penyuluhan memiliki kriteria rendah dengan skor rata-rata 2,57. Pertemuan secara daring dimunculkan akibat adanya virus corona. Petani merasa lebih efektif apabila terdapat pertemuan langsung daripada melalui virtual seperti obrolan menggunakan grup di whatsapp. Banyak petani juga yang tidak mengerti menggunakan smartphone. Dengan demikian, petani tidak siap untuk melakukan perubahan dalam menggunakan teknologi informasi yang semakin maju.

\section{Modal Sosial yang Diukur dari Indikator Jaringan Petani}

Jaringan adalah hubungan yang dimiliki oleh para petani dengan petani lainnya untuk membentuk suatu kelompok atau kemitraan. Sebelum membentuk suatu jaringan antar petani, setiap petani telah memiliki rasa kepercayaan agar terbentuklah jaringan. Jaringan antar petani ini diukur dari lima pertanyaan yaitu partisipasi setiap individu dalam kelompok tani, hadir dalam setiap pertemuan yang diadakan, aktif menyampaikan aspirasi, usul, dan pendapat, berkontribusi dengan tenaga, waktu, dan materi/uang, serta saling bertukar informasi mengenai usahatani jagung.

Tabel 5. Modal Sosial yang diukur berdasarkan Jaringan antar Petani

\begin{tabular}{llrl}
\hline No. & Indikator & $\begin{array}{c}\text { Skor rata- } \\
\text { rata }\end{array}$ & Kriteria \\
\hline 1 & Partisipasi setiap individu dalam kelompok tani & 3,40 & Sedang \\
2 & Hadir dalam setiap pertemuan yang diadakan & 3,27 & Sedang \\
3 & Aktif menyampaikan aspirasi, usul, dan pendapat & 3,01 & Sedang \\
4 & Berkontribusi dengan tenaga, waktu, dan materi/uang & 3,18 & Sedang \\
5 & Saling bertukar informasi mengenai usahatani jagung & 3,01 & Sedang \\
\hline & Jumlah & 15,87 & \\
& Rata-rata & 3,17 & Sedang \\
\hline
\end{tabular}

Pada indikator pengukuran pertama yaitu partisipasi setiap individu dalam kelompok tani memiliki skor rata-rata 3,40 dengan kriteria sedang. Partisipasi petani yang dimaksud adalah bergabung dalam kelompok tani. Petani yang ingin bergabung dalam kelompok tani atas kemauan sendiri. Partisipasi petani ini dapat didukung dengan empat indikator lainnya.

Indikator pengukuran yang kedua yaitu hadir dalam setiap pertemuan yang diadakan memiliki kriteria sedang dengan skor rata-rata 3,27. Pertemuan yang diadakan dalam satu bulan sebanyak dua kali pertemuan yang didampingi oleh penyuluh. Jika terdapat permasalahan dalam melakukan kegiatan usahatani biasanya dalam satu minggu terdapat dua kali pertemuan. Permasalahan yang dihadapi pada lahan jagung adalah terdapatnya hama wereng.

Indikator pengukuran ketiga adalah aktif menyampaikan aspirasi, usul, dan pendapat memiliki kriteria sedang dengan skor rata-rata 3,01. Petani mengeluarkan permasalahan 
yang dihadapi saat pertemuan. Adapun pendapat petani yang sering disampaikan adalah kekurangan pupuk. Padahal pupuk yang digunakan petani sebenarnya sudah cukup, tetapi beberapa petani masih mengeluhkan kalau pupuk tidak diberikan dengan maksimal.

Indikator yang keempat adalah berkontribusi dengan tenaga, waktu, dan materi/uang memiliki kriteria sedang dengan skor 3,18. Beberapa petani masih merasa keberatan apabila harus mengeluarkan uang untuk kepentingan bersama seperti membersihkan saluran, parit, dan pintu air. Petani masih mementingkan kepentingan pribadi dibandingkan kepentingan bersama.

Indikator yang kelima adalah saling bertukar informasi mengenai usahatani jagung memiliki kriteria sedang dengan skor rata-rata 3,01. Para petani di desa penelitian hanya sedikit yang melakukan interaksi dengan petani di desa lain. Hal ini membuat jaringan petani tidak luas sehingga informasi yang didapatkan juga masih sedikit. Tidak hanya itu, komunikasi antar petani di desa tersebut juga jarang dilakukan mengenai usahatani jagung. Jika dihubungkan dengan kesiapan para petani dalam menghadapi teknologi informasi pada indikator kepercayaan petani yang masih dikategorikan rendah, maka informasi yang didapatkan juga akan lebih minim sehingga antar petani tidak ada yang didiskusikan.

\section{Status Keberlanjutan Usahatani Jagung di Kecamatan Tanjung Lago}

Analisis modifikasi Rap-Fish yang terdiri atas tiga dimensi berkelanjutan. Tiga dimensi tersebut adalah dimensi sosial, dimensi ekonomi, dan dimensi lingkungan. Pengukuran dari ketiga dimensi tersebut diukur menggunakan 24 indikator atau disebut dengan atribut pada penggunaan Rap-fish. Hasil analisis menunjukkan bahwa peluang keberlanjutan usahatani jagung di Kecamatan Tanjung Lago Kabupaten Banyuasin bernilai 54,47 \% artinya cukup berkelanjutan. Jika dibandingkan dengan penelitian yang dilakukan oleh Atmika, 2021 yang meneliti mengenai keberlanjutan menggunakan lima dimensi menyatakan bahwa usahatani padi gogo di Kabupaten Bali Provinsi Bali memiliki indeks keberlanjutan sebesar 44,63 yang berarti kurang berkelanjutan.

Tabel 6. Status Keberlanjutan Usahatani Jagung di Kecamatan Tanjung Lago, Kabupaten Banyuasin

\begin{tabular}{lrrrc}
\hline $\begin{array}{c}\text { Dimensi } \\
\text { Keberlanjutan }\end{array}$ & Nilai Indeks (\%) & $\begin{array}{c}\text { Nilai } \\
\text { S-Stress }\end{array}$ & RSQ & $\begin{array}{c}\text { Status } \\
\text { Keberlanjutan }\end{array}$ \\
\hline Sosial & 57,71 & 0,16 & 0,92 & Cukup \\
Ekonomi & 56,58 & 0,17 & 0,94 & Cukup \\
Lingkungan & 49,12 & 0,16 & 0,94 & Kurang \\
\hline Rata-rata & 54,47 & & & Cukup \\
\hline
\end{tabular}

Nilai S-Stress masing-masing dimensi lebih rendah dari 0,25. Menurut goodness of fit hasil modifikasi Rap-Fish dapat mempresentasikan model dengan baik apabila nilai SStress tersebut berada di bawah 0,25. Maka, analisis modifikasi Rap-Fish keberlanjutan usahatani jagung telah menginterpretasikan model dengan baik.

Nilai RSQ yang bernilai semakin mendekati angka 1,00 menerangkan bahwa data yang ada akan terpetakan dengan sempurna. Hasil analisis diketahui nilai RSQ ketiga dimensi 
keberlanjutan memiliki nilai mendekati angka 1, sehingga keberlanjutan usahatani jagung telah terpetakan dengan sempurna.

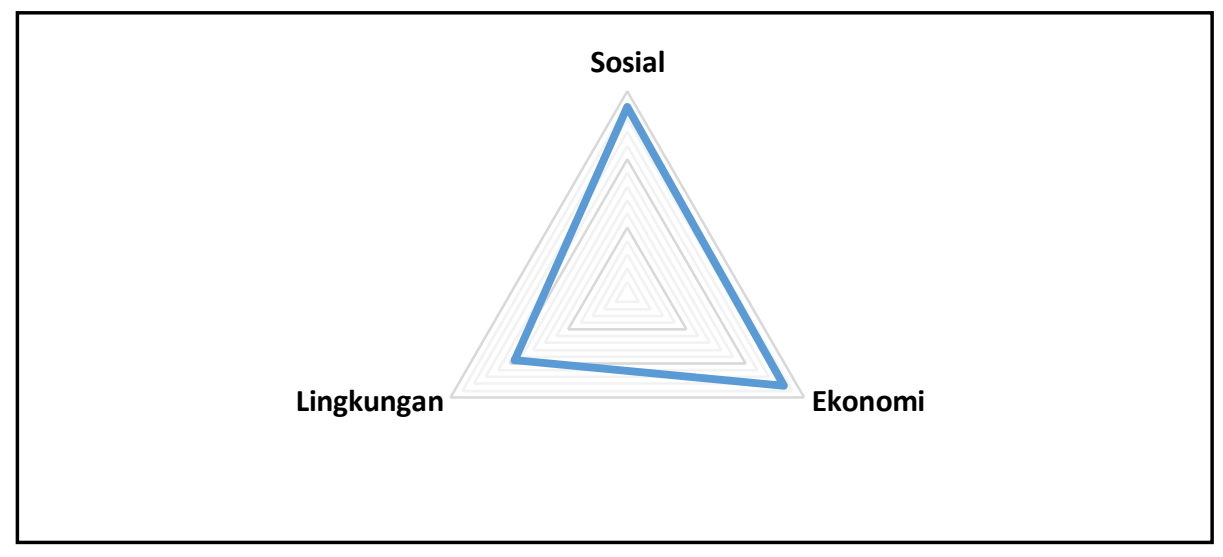

Gambar 1. Diagram Segitiga Tingkat Keberlanjutan Usahatani Jagung

\section{Dimensi Sosial}

Dimensi sosial menggunakan 8 atribut yaitu taat aturan, hubungan kekerabatan, peminjaman alsintan, partisipasi petani, kontribusi petani, mendapat banyak informasi, pendidikan, dan keberadaan kelembagaan yang membantu. Berdasarkan hasil analisis Rap-Fish tingkat keberlanjutan pada dimensi sosial usahatani jagung di Kecamatan Tanjung Lago, Kabupaten Banyuasin diperoleh nilai 57,71\% yang dikategorikan cukup berkelanjutan.

Analisis pengungkit (Leverage) adalah analisis yang menunjukkan sensitivitas pada setiap atribut terhadap nilai keberlanjutan dan dipakai untuk mengetahui atribut-atribut yang sensitif. Berdasarkan hasil dari analisis Leverage dimensi sosial terdapat terdapat 1 atribut yang lebih berpengaruh terhadap keberlanjutan usahatani jagung yaitu atribut Keberadaan Kelembagaan yang Membantu dengan nilai 8,43 yang paling besar dibandingkan atribut lainnya. Oleh karena itu, untuk meningkatkan keberlanjutan pada usahatani jagung di Kecamatan Tanjung Lago, Kabupaten Banyuasin perlu memperhatikan atribut tersebut. Sedangkan atribut lainnya adalah mendapatkan banyak informasi dengan nilai 1,65. Petani saling bertukar informasi antar petani terutama mengenai kegiatan usahatani jagung. Hal ini ditandai dengan atribut hubungan kekerabatan antar petani dengan nilai 0,98 berarti kekerabatan petani sudah baik. Lalu, persepsi petani mengenai pendidikan bernilai 0,83 , peminjaman alat/mesin pertanian bernilai 0,66, partisipasi petani terhadap kelompok tani bernilai 0,50, kontribusi petani 0,35, dan taat aturan bernilai 0,17. Ketujuh atribut ini berarti sudah berperan dengan baik bagi petani di Kecamatan Tanjung Lago, Kabupaten Banyuasin.

\section{Dimensi Ekonomi}

Berdasarkan hasil analisis Rap-Fish diketahui nilai tingkat keberlanjutan pada dimensi ekonomi pada usahatani jagung di Kecamatan Tanjung Lago adalah 56,58\%. Nilai keberlanjutan tersebut termasuk dalam kategori cukup berkelanjutan. 
Analisis Leverage untuk atribut dimensi ekonomi pada usahatani jagung di Kecamatan Tanjung Lago, Kabupaten Banyuasin menunjukkan bahwa 4 atribut yang mempunyai daya ungkit tinggi yaitu kemudahan akses pasca panen, manfaat teknologi yang dapat menambah keuntungan, pasar produk yang memadai, dan pendapatan non usahatani. Upaya peningkatan tingkat keberlanjutan pada usahatani jagung di Kecamatan Tanjung Lago, Kabupaten Banyuasin dari dimensi ekonomi perlu memperhatikan keempat atribut tersebut.

Atribut keuntungan usahatani jagung dalam jangka panjang dan memiliki modal sendiri masing-masing bernilai 0,11 dan 0,32. Nilai tersebut memiliki nilai yang rendah dibandingkan empat atribut sensitif lainnya. Petani berpendapat keuntungan jagung memang besar namun tidak dalam jangka panjang karena modal yang dikeluarkan juga besar. Dengan demikian, petani yang tidak memiliki modal yang banyak, maka akan meminjam uang. Petani dapat meminjam berupa uang maupun dalam bentuk pupuk.

\section{Dimensi Lingkungan}

Analisis tingkat keberlanjutan dari dimensi lingkungan pada usahatani jagung di Kecamatan Tanjung Lago, Kabupaten Banyuasin menggunakan 10 atribut dalam penentuannya. Adapun atribut tersebut adalah jenis varietas benih yang digunakan oleh petani, jumlah benih yang digunakan oleh petani dalam satu hektar, penggunaan kapur, pengendalian hama dan penyakit tanaman, mengetahui tentang reduce, menerapkan reduce, memiliki motivasi untuk reuse, mengetahui keuntungan apabila melakukan reuse, mengetahui manfaat recycle, dan menerapkan recycle.

Hasil analisis keberlanjutan menggunakan Rap-Fish untuk tingkat keberlanjutan usahatani jagung di Kecamatan Tanjung Lago, Kabupaten Banyuasin dari dimensi lingkungan menunjukkan nilai sebesar $49,12 \%$ yang memiliki arti bahwa tingkat keberlanjutan usahatani jagung di Kecamatan Tanjung Lago, Kabupaten Banyuasin dari dimensi sosial adalah kurang berkelanjutan.

Berdasarkan analisis Leverage pada atribut dimensi sosial diketahui terdapat tiga atribut yang mempunyai daya ungkit tinggi yaitu atribut jenis varietas benih, jumlah benih per hektar, dan penerapan recycle. Masing-masing atribut tersebut memiliki nilai sebesar $5,03,3,04$, dan 4,22. Hal ini berarti bahwa dalam merumuskan kebijakan upaya meningkatkan tingkat keberlanjutan dari dimensi lingkungan perlu memperhatikan dan mempertimbangkan tiga atribut tersebut.

Atribut penggunaan kapur di lahan dan pengendalian hama dan penyakit tanaman (HPT) memiliki nilai 0,23 dan 0,18 . Lalu, atribut paham tentang reduce bernilai 0,71 , menerapkan reduce bernilai 1,01, memiliki motivasi reuse bernilai 0,76 , mengetahui keuntungan reuse bernilai 0,53 , dan manfaat recycle bernilai 1,35 . Nilai ini menggambarkan bahwa atribut-atribut tersebut hanya memberikan kontribusi sebesar nilai tersebut terhadap keberlanjutan dimensi lingkungan. Hal ini sesuai dengan kondisi di lapangan bahwa petani di Kecamatan Tanjung Lago, Kabupaten Banyuasin sudah memanfaatkan kapur di lahan dengan tepat untuk jenis lahan yang asam dan mengendalikan HPT juga dengan tepat. petani di lokasi penelitian rata-rata sudah 
mengetahui mengenai reduce, reuse, dan recycle. Namun, petani belum menerapkan recycle dari limbah usahatani jagung.

Limbah usahatani jagung tidak diolah dengan baik, hanya dibiarkan dan ditumpuk saja di sekitar lahan. Petani tidak melakukan pembakaran karena takut akan ditangkap oleh aparat yang bertanggung jawab. Dengan demikian, petani hanya membiarkan saja. Pengolahan limbah juga belum diketahui oleh petani jagung. Hal ini dikarenakan petani belum memiliki pengetahuan tersebut karena belum ada penyuluhan mengenai pengolahan limbah. Upaya peningkatan tingkat keberlanjutan dari dimensi lingkungan dapat dilakukan dengan menyelesaikan permasalahan yang ada dengan cara penyuluhan.

\section{KESIMPULAN}

Berdasarkan hasil analisis menggunakan skala Likert bahwa pengukuran indikator modal sosial petani di Kecamatan Tanjung Lago, Kabupaten Banyuasin memperoleh skor 3,24 artinya modal sosial petani termasuk dalam kriteria sedang. Petani di Kecamatan Tanjung Lago masih kurang memiliki rasa percaya terhadap petani lainnya.

Keberlanjutan usahatani jagung Kecamatan Tanjung Lago Kabupaten Banyuasin bernilai $54,47 \%$ artinya cukup berkelanjutan. Hal ini didukung oleh dua dimensi lainnya yang berada pada kriteria cukup yaitu dimensi sosial dan dimensi ekonomi. Sedangkan dimensi lingkungan masih berada pada kategori kurang berkelanjutan.

\section{SARAN}

Petani sebaiknya menumbuhkan rasa percaya satu sama lain agar terbentuknya jaringan yang baik antar petani sehingga munculnya rasa aman dalam melakukan segala kegiatan terutama usahatani jagung. Kepada pemerintah daerah dan instansi terkait dapat mendukung petani dalam kegiatan usahatani jagung terutama dari aspek lingkungan serta meningkatkan dari aspek sosial dan ekonomi.

\section{DAFTAR PUSTAKA}

Atmika, I. M., Sudarma, dan Ketut B.S. 2021. Status Keberlanjutan Usahatani Padi Gogo di Kabupaten Bangli Provinsi Bali. Jurnal Manajemen Agribisnis. 9(1) : 220 234.

Harahap, M. dan Surna, H. 2018. Hubungan Modal Sosial dengan Produktivitas Petani Sayur (Studi Kasus Pada Kelompok Tani Barokah Kelurahan Tanah Enam Ratus Kecamatan Medan Marelan). Agrium. 21(2).

Honorita, B., Herwenita, dan Susilawati. 2019. Potensi Modal Sosial Dalam Kelompok Tani Sampoerna Dan Implikasinya Terhadap Perilaku Petani Di Dalam Budidaya Jagung Hibrida. Prosiding Temu Teknis Jabatan Fungsional Non Peneliti.

Khaswarina, S. dan Eliza. 2018. Analisis Keberlanjutan Perkebunan Karet Di Pulau Sarak Kabupaten Kampar Riau. Jurnal Ilmu-ilmu Sosial dan Humaniora. Vol. 20(1): 65 -69 . 
Mamahit, Y., Wangke, W. M., dan Benu, N. M. 2016. Kajian Modal Sosial Pada Kelompok Tani Di Desa Tumani Kecamatan Maesaan Kabupaten Minahasa Selatan. Agri-sosioekonomi. 12(2A):125-136.

Pratiwi, N. K. G., Wayan S. dan Ni Wayan S. A. 2017. Peran Modal Sosial dalam Membangun Jejaring Pemasaran Formalin Nabati dari Tanaman Lamtoro Berbasis Kelompok Tani. E-Jurnal Agribisnis dan Agrowisata. 6(3) : 450-459.

Solikatun dan Nuning J. 2018. Modal Sosial Sebagai Strategi Bertahan Hidup Masyarakat Desa Maria, Kecamatan Wawo, Kabupaten Bima, Provinsi Nusa Tenggara Barat. Jurnal Analisa Sosiologi. 7(2). 